\section{'Cara's Choice' Blueberry}

\author{
Mark K. Ehlenfeldt and Allan W. Stretch ${ }^{1}$
}

U.S. Department of Agriculture, Agricultural Research Service, Marucci Center for Blueberry and Cranberry Research and Extension, 125A Lake Oswego Road, Chatsworth, NJ 08019

\section{Nicholi Vorsa ${ }^{2}$ \\ Rutgers University, Rutgers Blueberry and Cranberry Research Center, $125 \mathrm{~A}$ Lake Oswego Road, Chatsworth, NJ 08019}

\author{
Arlen D. Draper ${ }^{3}$ \\ 604 East Park Drive, Payson, AZ 85541
}

Additional index words. fruit breeding, Vaccinium, tetraploid

Abstract. 'Cara's Choice' is a mid-season ripening, tetraploid, hybrid blueberry (Vaccinium $x$ 'Cara's Choice') that was developed by the cooperative breeding program of the Agricultural Research Service of the U.S. Department of Agriculture (USDA) and the New Jersey Agricultural Experiment Station (NJAES). 'Cara's Choice'was given its name in recognition of its excellent fruit quality with improved sweetness, firmness, and flavor. complex and aromatic. Its fruit are uniformly medium sized, medium- to light-blue, with dry scars, and excellent firmness (Fig. 2). A detailed comparison of fruit characteristics of' 'Cara's Choice', 'Weymouth'(Coville, 1937), 'Duke' (Draper, et al. 1987), and 'Bluecrop' (Draper and Hancock, 1990) (Table 1) shows 'Cara's Choice' to be superior to 'Weymouth' in berry size, color, firmness, and soluble solids. Its size is smaller than 'Duke' or 'Bluecrop', but is superior in firmness and soluble solids. The high levels of soluble solids in 'Cara's Choice' represent an approximate 20\% to $25 \%$ relative increase in soluble solids over the average values for 'Duke' and 'Bluecrop'. A further distinctive feature is its ability to retain quality on the bush for several weeks, without significant declines in sweetness, acidity, firmness, or flavor. The estimated date for $50 \%$ ripe fruit was 27 June to 11 July, and averaged 4 July, about 8 d later than 'Duke' and about $5 \mathrm{~d}$ earlier than 'Bluecrop'. Yield in New Jersey on mature plants in 1999-2001 in mixed plantings has been $56 \%$ of 'Duke',

\section{Origin}

'Cara's Choice', tested as G-695, originated from the cross G-144 $\times$ US 165 . This cross was made by A.D. Draper at Beltsville, Md., in about 1977 and is notable for having the diploid species selection Vaccinium darrowi Camp 'Florida 4B', and the hexaploid species, V. constablaei Gray and V. ashei Reade (rabbiteye) in its ancestry (Fig. 1). 'Cara's Choice'was selected in 1981 from a seedling-field grown at the Atlantic Blueberry Co. Hammonton, N.J., by A.D. Draper. It was subsequently evaluated by A.D. Draper, G.J. Galletta, G. Jelenkovic, N. Vorsa, A.W. Stretch, and M.K. Ehlenfeldt at Atlantic Blueberry Co. from 1983 through 1996 in test rows of vegetatively propagated clones, and at Variety Farms, Hammonton, N.J., from 1996 to 2001 in a replicated planting of elite clones and standard cultivars, consisting of four replications of five plants, each in a randomized complete block design. Both the Atlantic Blueberry Co. and the Variety Farms trials were located on farms in USDA Plant Hardiness Zone 6, on soils that are mostly Atsion sand containing $3 \%$ to $15 \%$ organic matter. Cultural practices at Atlantic Blueberry Co. included the use of solid set irrigation for irrigation and frost protection. The yield trial plots at Variety Farms used similar practices with the addition of incorporating peat to the planting holes and mulching with pine bark. 'Cara's Choice' was introduced in 2000.

\section{Description}

Evaluation of the original 'Cara's Choice' plant and evaluations of subsequently propagated plants established in a replicated trial at Hammonton, N.J., during 1993-2001 indicated that the most impressive traits of 'Cara's Choice' were very sweet fruit, with balanced acidity, and an outstanding flavor that is both

Received for publication 12 Dec. 2004. Accepted for publication 23 Jan. 2005.



Fig. 1. Pedigree of 'Cara's Choice' highbush blueberry.

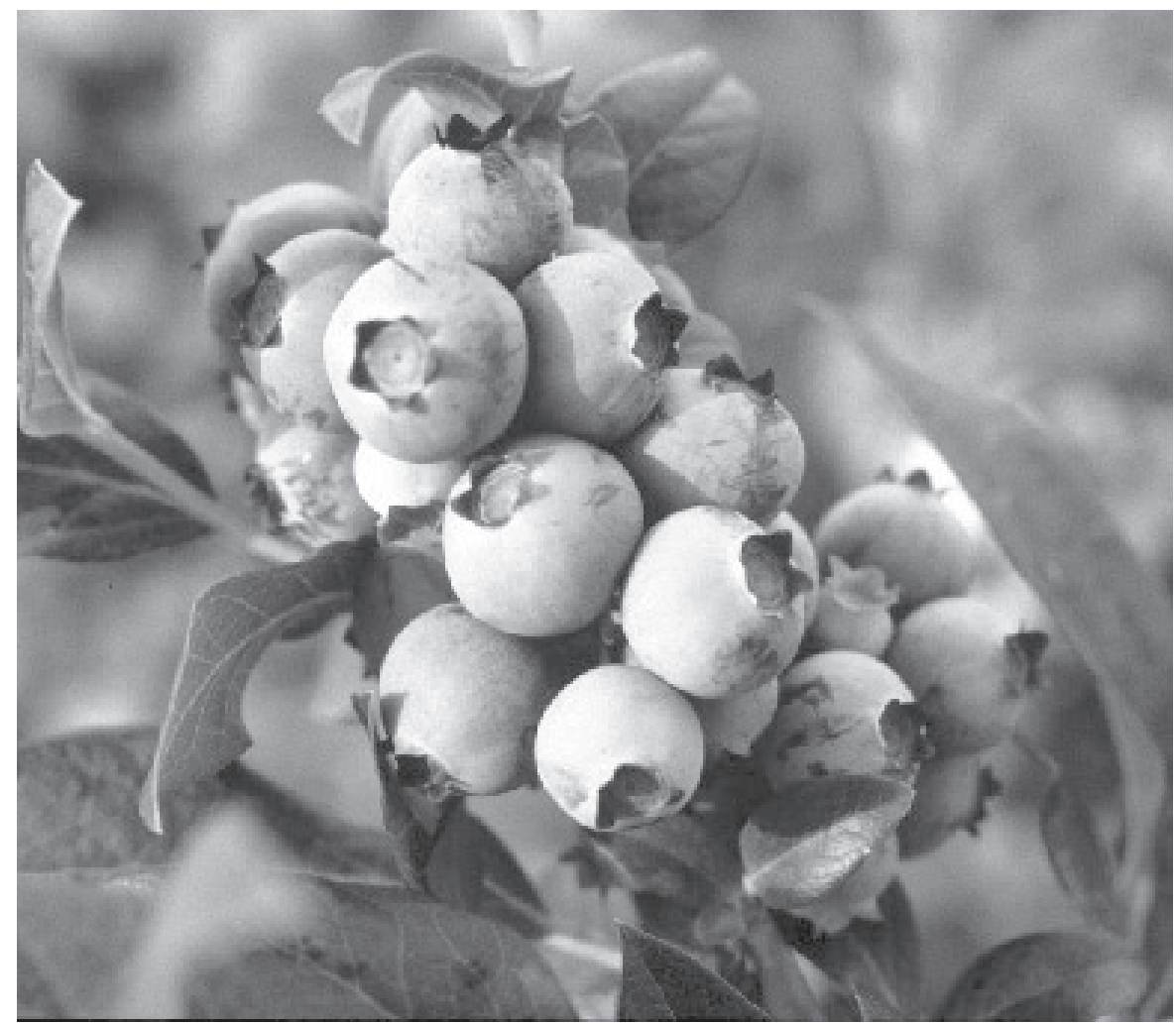

Fig. 2. Fruit of 'Cara's Choice' highbush blueberry. 
Table 1. Fruit weight, color, firmness, soluble solids, titratable acidity, estimated 50\% ripening dates, and representative yields for 'Weymouth', 'Duke', 'Bluecrop', and 'Cara's Choice' summarized across all harvests at Variety Farms in Hammonton, N.J., in 1996 through 2001. Plants were set in the field in 1993.

\begin{tabular}{|c|c|c|c|c|c|c|c|c|}
\hline Cultivar & $\begin{array}{l}\text { Berry } \\
\text { wt } \\
(\mathrm{g})\end{array}$ & $\begin{array}{l}\text { Color } \\
(\mathrm{L})^{\mathrm{z}}\end{array}$ & $\begin{array}{l}\text { Firmness } \\
\left(\mathrm{g} \cdot \mathrm{mm}^{-1}\right)^{\mathrm{y}}\end{array}$ & $\begin{array}{l}\text { Soluble } \\
\text { solids }^{\mathrm{x}}\end{array}$ & $\begin{array}{c}\text { Titratable } \\
\text { acidity } \\
(\% \text { citric acid })^{\mathrm{x}}\end{array}$ & $\begin{array}{l}\text { Date } \\
50 \% \\
\text { ripe }\end{array}$ & $\begin{array}{l}\text { Harvest } \\
\text { interval }\end{array}$ & $\begin{array}{c}\text { Yield/ } \\
\text { plant } \\
(\mathrm{kg})\end{array}$ \\
\hline \multicolumn{9}{|l|}{ Cara's Choice } \\
\hline 1996 & --- & --- & --- & --- & --- & --- & --- & --- \\
\hline 1998 & 1.6 & 29 & 161 & 13.4 & 0.67 & 27 June & 24 June-27 July & 3.6 \\
\hline 1999 & 1.5 & 29 & 150 & 12.6 & 0.66 & 11 July & 29 June-3 Aug & 2.6 \\
\hline 2000 & 1.1 & 36 & 161 & 12.8 & 0.82 & 2 July & 27 June-24 July & 3.3 \\
\hline 1996 & 1.5 & 22 & 128 & 12.2 & 0.60 & 23 June & 21 June-8 July & --- \\
\hline 1997 & 1.7 & 24 & 125 & 11.3 & 0.94 & 24 June & 20 June-7 July & --- \\
\hline 1998 & 1.6 & 21 & 126 & 9.4 & 0.54 & 17 June & 16 June-29 June & 3.7 \\
\hline 1999 & 1.0 & 25 & 124 & 10.1 & 0.51 & 24 June & 15 June-7 July & 3.7 \\
\hline 2000 & 0.8 & 28 & 125 & 9.7 & 0.60 & 23 June & 20 June-5 July & 3.4 \\
\hline 2001 & 1.2 & 27 & 152 & 10.7 & 0.80 & 18 June & 15 June-2 July & 2.8 \\
\hline \multicolumn{9}{|l|}{ Duke } \\
\hline 2001 & 1.8 & 30 & 147 & 11.0 & 0.44 & 24 June & 18 June-9 July & 3.5 \\
\hline \multicolumn{9}{|l|}{ Bluecrop } \\
\hline 1996 & 2.0 & 27 & 113 & 11.7 & 0.65 & 10 July & 8 July-5 Aug & --- \\
\hline 1997 & 1.9 & 28 & 110 & 11.3 & 0.80 & 13 July & 11 July-28 July & --- \\
\hline 1998 & 1.8 & 27 & 126 & 10.6 & 0.80 & 5 July & 24 June-21 July & 5.4 \\
\hline 1999 & 1.6 & 30 & 138 & 10.5 & 0.70 & 14 July & 29 June-3 Aug & 6.0 \\
\hline 2000 & 1.3 & 34 & 128 & 11.1 & 0.70 & 5 July & 27 June-31 July & 4.5 \\
\hline 2001 & 1.7 & 31 & 124 & 12.9 & 0.80 & 5 July & 2 July - 24 July & 3.7 \\
\hline \multicolumn{9}{|c|}{ 1996-2001 averagesw } \\
\hline Cara's Choice & $1.5 \mathrm{~b}$ & $32 \mathrm{c}$ & $159 \mathrm{~b}$ & $13.3 \mathrm{c}$ & $0.73 \mathrm{~b}$ & 4 July c & 28 June-28 July & $3.1 \mathrm{a}^{\mathrm{v}}$ \\
\hline Weymouth & $1.3 \mathrm{a}$ & $25 \mathrm{a}$ & $130 \mathrm{a}$ & $10.6 \mathrm{ab}$ & $0.67 \mathrm{~b}$ & 22 June a & 17 June-3 July & $3.4 \mathrm{a}$ \\
\hline Duke & $1.8 \mathrm{c}$ & $29 \mathrm{~b}$ & $148 \mathrm{~b}$ & $10.2 \mathrm{a}$ & $0.44 \mathrm{a}$ & 26 June b & 19 June-9 July & $5.5 \mathrm{~b}$ \\
\hline Bluecrop & $1.7 \mathrm{c}$ & $30 \mathrm{~b}$ & $123 \mathrm{a}$ & $11.4 \mathrm{~b}$ & $0.74 \mathrm{~b}$ & 9 July d & 28 June-28 July & $4.9 \mathrm{~b}$ \\
\hline
\end{tabular}

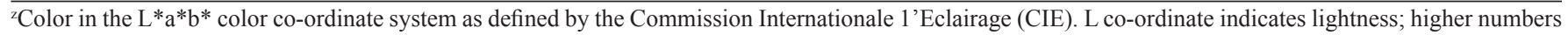
indicate lighter color. Color meter aperture, $50 \mathrm{~mm}$.

${ }^{\mathrm{y}} \mathrm{Grams}$ of force needed to produce $1 \mathrm{~mm}$ of deflection, averaged across 30 intact fruit.

${ }^{x}$ Soluble solids and titratable acidity were determined on a blended one cup sample of fruit.

wAnalysis of variance performed using the SAS GLM procedure (SAS Institute, Cary, N.C.). Means within columns with different letters are significant at the 0.05 level.

'Yield averages represent yield across 1998-2001, when plants had reached mature stature.

and $63 \%$ of 'Bluecrop' (Table 1). Yields have been remarkably stable.

'Cara's Choice' is an moderate to lowgrowing bush, that flowers slightly later than 'Bluecrop' in most years, but may flower almost as early as 'Weymouth' in others. It has distinctive blue-green foliage, which makes it easily recognizable in comparison to most northern highbush blueberry cultivars. Studies in New Jersey have shown that 'Cara's Choice' is relatively resistant to mummy berry blight caused by the fungus Monilinia vaccinii-corymbosi Reade (Honey) (ranking 25 in a group of 76 cultivars), and has average resistance (ranking 39 out of 76) to the secondary, mummy berry fruit-infection stage (unpublished data). 'Cara's Choice' is relatively susceptible to anthracnose fruit-rot (ranking 71 out of 100), but is better than 'Bluecrop' (92 of 100) and 'Blueray' (81 of 100) (Polashock et al., 2005). 'Cara's Choice' produces moderate yields in New Jersey, but is untested in most other regions. Because it has medium fruit size and relatively low yields, it is highly recommended that 'Cara's Choice' be planted with another cultivar to obtain the benefits of cross-pollination on size and yield. 'Cara's Choice' is recommended as a midseason, high-quality, specialty cultivar primarily for commercial growers, pick-your-own growers, and home growers in northeastern temperate regions, including New Jersey and adjoining states. The presence of southern-species germplasm this cultivar's genetic background suggests it may also do well in more southerly areas.

\section{Availability}

Plants of 'Cara's Choice' have been distributed to commercial propagators; neither the USDA nor NJAES currently has plants for distribution. Growers may request information on how to obtain propagules by contacting $\mathrm{M}$. K. Ehlenfeldt, USDA-ARS, at the Phillip E. Marucci Blueberry and Cranberry Research and Extension Center, 125A Lake Oswego Road, Chatsworth, NJ 08019. Genetic material of this release has been deposited in the National Plant Germplasm System where it will be available for research purposes.

\section{Literature Cited}

Coville, F.A. 1937. Improving the Wild Blueberry, p. 559-574. In: Yearbook of agriculture. U.S. Dept. Agr., Wash., D.C.

Draper, A., G. Galletta, G. Jelenkovic, and N. Vorsa. 1987. 'Duke' highbush blueberry. HortScience 22:320.

Draper, A. and J. Hancock. 1990. The 'Bluecrop' highbush blueberry. Fruit Var. J. 44:2-3.

Polashock, J.J., M.K. Ehlenfeldt, A.W. Stretch, and M. Kramer. 2005. Anthracnose fruit-rot resistance in blueberry cultivars. Plant Dis. 89:33-38. 